\title{
Phytosulfokine- $\alpha$, a Peptidyl Plant Growth Factor, Stimulates Cell Cycle Progression in Carrot Non-Embryogenic Cells
}

\author{
Chang-Ho EUN ${ }^{1}$, Suk-Min KO ${ }^{1}$, Katsumi HIGASHI ${ }^{1}$, Dennis YEO ${ }^{1}$, Yoshikatsu MATSUBAYASHI ${ }^{2}$, \\ Youji SAKAGAMI ${ }^{2}$ and Hiroshi KAMADA ${ }^{1}$ \\ ${ }^{\prime}$ Gene Research Center, Institute of Biological Sciences, University of Tsukuba, \\ Tsukuba, Ibaraki 305-8572, Japan \\ ${ }^{2}$ School of Agricultural Sciences, Nagoya University, Chikusa, Nagoya 464-0814, Japan \\ *Corresponding author E-mail address: eun@sakura.cc.tsukuba.ac.jp \\ Received 22 November 2002; accepted 19 December 2002
}

\begin{abstract}
Peptidyl plant growth factor phytosulfokine- $\alpha$ (PSK- $\alpha$ ) is known to stimulate both cell proliferation and differentiation, the mechanism for which, however, has yet to be elucidated. We here investigated the effects of PSK $-\alpha$ on cell cycle regulation using non-embryogenic cell cultures of carrot. Flow cytometric analysis of cell nuclear DNA content showed that the addition of PSK - $\alpha$ $\left(1 \times 10^{-7} \mathrm{M}\right)$ to a medium containing a low concentration $\left(4.5 \times 10^{-7} \mathrm{M}\right)$ of 2,4 -dichlorophenoxyacetic acid $(2,4-D)$ promoted progression of the G1 cell cycle. Similar results were obtained with a high $2,4-$ $\mathrm{D}\left(4.5 \times 10^{-6} \mathrm{M}\right)$ medium lacking PSK $-\alpha$. PSK $-\alpha$ appeared to be involved in cell cycle progression outside the G1 phase. RT-PCR using cell cycle-related genes from carrot showed that the amounts of the transcripts of these genes were increased by the addition of PSK - $\alpha$, and the levels of which were very similar to those with high $2,4-\mathrm{D}$ medium. The timing of the transcript increase roughly corresponded to that of the cell cycle progression. PSK - $\alpha$ seemed to stimulate re-entry of quiescent cells into the cell cycle. We propose a mechanism that PSK - $\alpha$ stimulates cell proliferation through the cell cycle regulation.
\end{abstract}

Key words: cell cycle, Daucus carota, flow cytometry, non-embryogenic cells, phytosulfokine $-\alpha$.

\section{Abbreviations}

$\mathrm{CM}$, conditioned medium; FCM, flow cytometry; MS medium, Murashige and Skoog's medium; $\mathrm{PCV}$, packed cell volume after centrifugation at 100 g; PGRs, plant growth regulators; PSK $-\alpha$, phytosulfokine- $\alpha$.

\section{Introduction}

Although plant cell proliferation is dependent mainly on the action of plant growth regulators (PGRs) such as auxin and cytokinin, both in vivo and in vitro, in suspension cultures it is also strongly dependent on cell density. In low cell density suspension cultures, mitotic activity is not promoted by supplementation with known PGRs or defined nutrients. It is, however, stimulated by the addition of conditioned medium (CM) prepared from suspension cultures of rapidly growing cells. One possible explanation for this phenomenon is that a mitogenic factor or other unknown factors produced by indi- vidual cells is secreted into the CM (Stuart and Street, 1969; Bellincampi and Morpurgo, 1987, 1989; Somers et al., 1987; Birnberg et al., 1988; Huang et al., 1990). For the past several decades, characterization of the mitogenic factor has been attempted in various culture systems. However, identification of the mitogenic factor(s) has been hampered by the lack of sufficiently sensitive assay methods (Bellincampi and Morpurgo, 1987; Birnberg et al., 1988; Schaffler et al., 1990).

A breakthrough came when two mitogenic factors identified in CM derived from asparagus mesophyll cell cultures (Matsubayashi and Sakagami, 1996). The structures of these factors were determined to be the sulfated pentapeptide PSK $-\alpha\left(\mathrm{H}-\mathrm{Tyr}\left(\mathrm{SO}_{3} \mathrm{H}\right)\right.$ - Ile- $\left.\mathrm{Tyr}\left(\mathrm{SO}_{3} \mathrm{H}\right)-\mathrm{Thr}-\mathrm{Gln}-\mathrm{OH}\right)$ and the corresponding $\mathrm{C}$-terminal-truncated tetrapeptide PSK$\beta\left(\mathrm{H}-\mathrm{Tyr}\left(\mathrm{SO}_{3} \mathrm{H}\right)-\mathrm{Ile}-\mathrm{Tyr}\left(\mathrm{SO}_{3} \mathrm{H}\right)-\mathrm{Thr}-\mathrm{OH}\right)$. Subsequently, PSK $-\alpha$ has been detected in conditioned medium of suspension cultures derived from other monocotyledonous and dicotyledonous plants, such as rice (Matsubayashi et al., 1997), zinnia (Matsu- 
bayashi et al., 1999), and carrot (Hanai et al., 2000), showing that PSK $-\alpha$ has a broad distribution in higher plants.

In addition to its stimulatory effects on plant cell proliferation, PSK - $\alpha$ has several other biological activities, such as the promotion of adventitious root formation in cucumber hypocotyls (Yamakawa et al. 1998a), stimulation of chlorophyll production in etiolated cotyledons of cucumber (Yamakawa et al., 1998b), promotion of growth and increasing chlorophyll content of Arabidopsis seedlings grown under high night-time temperatures (Yamakawa et al, 1999), triggering of tracheary element differentiation of isolated zinnia mesophyll cells (Matsubayashi et al., 1999), stimulation of adventitious bud formation in Antirrhinum majus callus (Yang et al., 1999), contribution to the pollen population effect of tobacco (Chen et al., 2000), and promotion of somatic embryogenesis through stimulation of cell proliferation in carrot (Kobayashi et al., 1999; Hanai et al., 2000). Genes encoding precursors for PSK - $\alpha$ and receptors for PSK - $\alpha$ have been identified in rice, Arabidopsis thaliana, and carrot (Matsubayashi and Sakagami, 2000; Yang et al., 2000; Yang et al., 2001; Matsubayashi et al., 2002).

To date, however, the mechanism of PSK- $\alpha$ action in these cell culture has not been determined. We have hypothesized that PSK - $\alpha$ can stimulate cell proliferation through regulation of the cell cycle. In the present work, we have investigated the promotive effect of PSK - $\alpha$ on cell cycle progression by analysis of nuclear DNA content in carrot non-embryogenic cells using flow cytometry (FCM). We also examined changes in the expression of cell cycle-related genes after PSK $-\alpha$ treatment, using RT-PCR analysis. In this report, we used carrot non-embryogenic cells, since proliferation of carrot non-embryogenic cells is stimulated by exogenously applied PSK - $\alpha$ (Kobayashi et al., 1999).

\section{Materials and Methods}

\section{Plant materials and cell culture}

Non-embryogenic cell suspension cultures of Daucus carota L. cv. US-Harumakigosun (Satoh et al. 1986), which had lost the ability to form somatic embryos, were maintained in $100 \mathrm{ml}$ of Murashige and Skoog's (MS) liquid medium (Murashige and Skoog, 1962) containing 2,4-D $\left(4.5 \times 10^{-6} \mathrm{M}\right)$, in $300 \mathrm{ml}$ flasks, and the cultures were allowed to grow on a gyratory shaker $(100 \mathrm{rpm})$ at $25^{\circ} \mathrm{C}$ in darkness. Cells were transferred to $100 \mathrm{ml}$ of fresh MS medium containing 2,4-D at two-week intervals.

\section{Synchronization of the cell cycle}

Non-embryogenic cells cultured for seven days were treated to synchronize their cell cycles. In the propyzamide block release experiment, the twostep blocking method was used. The suspension culture was first transferred to fresh MS medium supplemented with $4.5 \times 10^{-6} \mathrm{M} 2,4-\mathrm{D}$ and $20 \mathrm{mg}$ $1^{-1}$ aphidicolin (Wako Pure Chemical). The cells were incubated for $72 \mathrm{~h}$, washed ten times with $3 \%$ $(\mathrm{w} / \mathrm{v})$ sucrose, and then incubated for $8 \mathrm{~h}$ in $100 \mathrm{ml}$ of fresh MS medium supplemented with $4.5 \times 10^{-6}$ M 2,4-D. Following the addition of $100 \mu 1$ of 6 $\mathrm{mM}$ propyzamide (Wako Pure Chemical), the cells were incubated for an additional $8 \mathrm{~h}$. They were

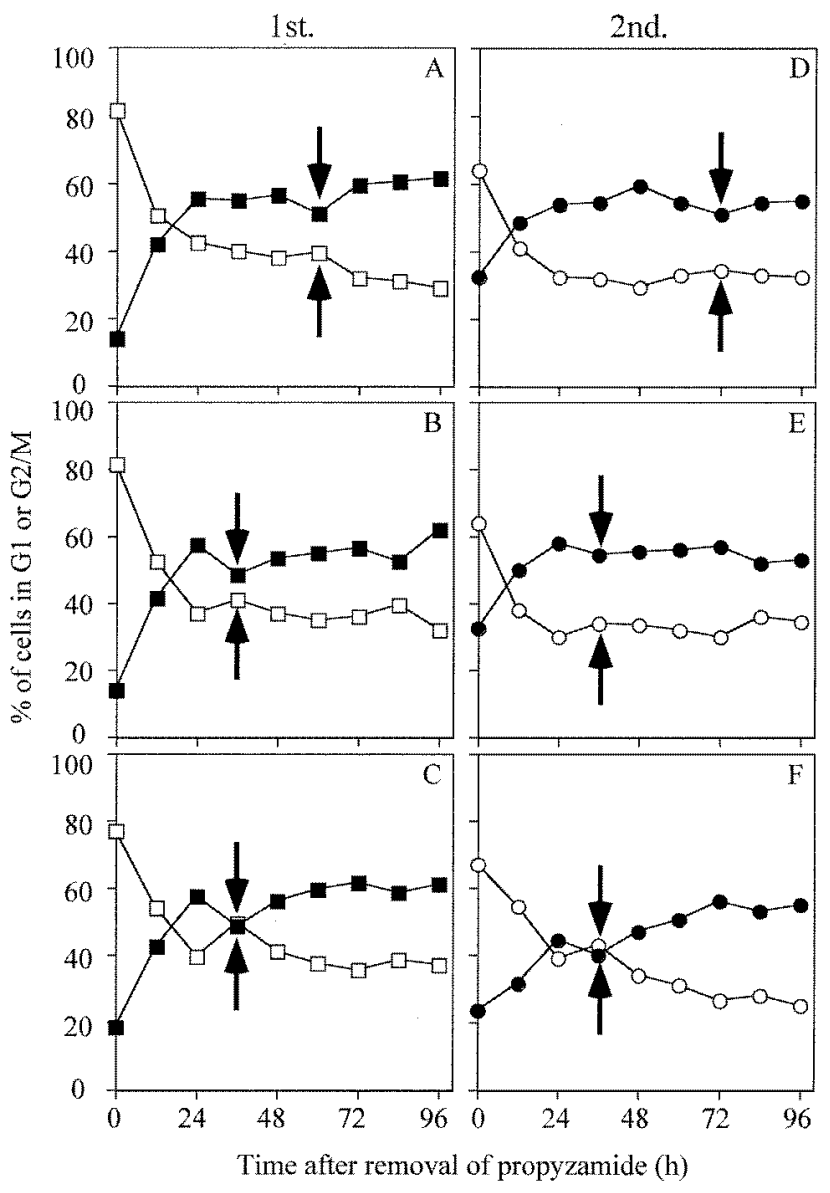

Fig. 1 Flow cytometry analysis of non-embryogenic cells after release from propyzamide blocking in $M$ phase. A time course of the accumulation of cells in $\mathrm{G} 1$ or $\mathrm{G} 2 / \mathrm{M}$ phases of the cell cycle was examined in cell suspensions cultured in the presence of a low concentration $\left(4.5 \times 10^{-7} \mathrm{M}\right)$ of 2,4-D without ( $A$ and $D$ ) or with (B and $E$ ) PSK $-\alpha\left(1 \times 10^{-7} \mathrm{M}\right)$, and in the presence of a high concentration $\left(4.5 \times 10^{-6} \mathrm{M}\right)$ of $2,4-\mathrm{D}$ without PSK - $\alpha$ (C and F). Closed and open symbols indicate the percentage of the cells accumulated in the $\mathrm{G} 1$ phase or $\mathrm{G} 2 / \mathrm{M}$ phases, respectively. Each experiment was performed in duplicate, and the results of each experiment are shown separately (1st and 2 nd experiment). 


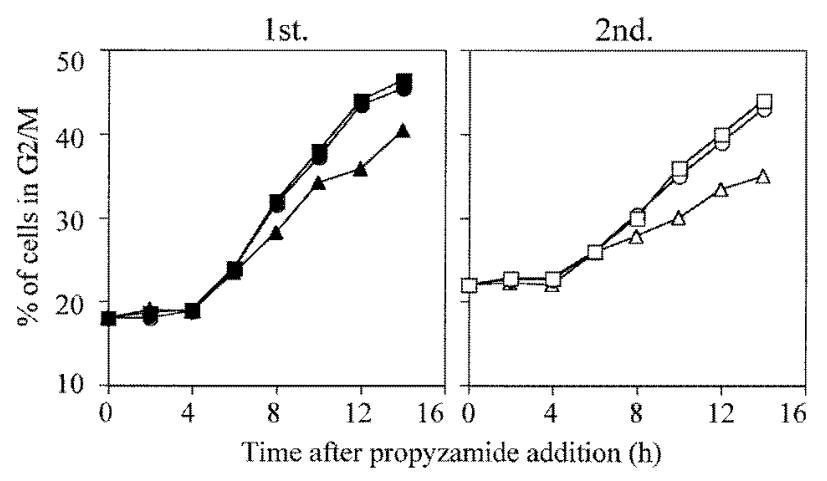

Fig. 2 Flow cytometry analysis of non-embryogenic cells after addition of propyzamide with aphidicolin blocking release. A time course of the accumulation of cells in the G2/M phase of the cell cycle was examined in cell suspensions cultured in the presence of a low concentration $\left(4.5 \times 10^{-7} \mathrm{M}\right)$ of $2,4-\mathrm{D}$ without $(\boldsymbol{\Delta}$ and $\boldsymbol{\Delta})$ or with ( and $\bigcirc)$ PSK - $\alpha\left(1 \times 10^{-7} \mathrm{M}\right)$, and in the presence of a high concentration $\left(4.5 \times 10^{-6}\right.$ M) of 2,4-D without PSK- $\alpha$ ( $\square$ and $\square$ ). Each experiment was performed in duplicate, and the results of each experiment are shown separately ( 1 st and 2 nd experiment).

then washed thoroughly with $3 \%$ sucrose and re suspended in $100 \mathrm{ml}$ of fresh MS medium containing a low concentration of $2,4-\mathrm{D}\left(4.5 \times 10^{-7} \mathrm{M}\right)$ with or without PSK $\alpha\left(1 \times 10^{-7} \mathrm{M}\right)$, or a high concentration of $2,4-\mathrm{D}\left(4.5 \times 10^{-6} \mathrm{M}\right)$ without PSK$\alpha$. Samples were collected at the time points indicated in Fig. 1. For the propyzamide addition experiment, cells were blocked in the $\mathrm{S}$ phase by treatment with aphidicolin, as described above. Simultaneously with the release from the aphidicolin, propyzamide was added, which triggered cells to accumulate in the $G 2 / \mathrm{M}$ phase. Samples were collected at the time points indicated in Fig. 2.

\section{Flow cytometry (FCM)}

For FCM, a Partec PA cytometer (Partec, Münster, Germany), equipped with a mercury lamp and combinations of KG1, BG38, UG1, TK420, and GG435 filters, was used. To isolate nuclei, a portion $(3 \mathrm{ml})$ of the suspension culture was collected after release from cell cycle blocking as described above. The collected cells were washed with $3 \%$ sucrose and treated for $30 \mathrm{~min}$ with an enzyme mixture: $2 \%$ cellulase, $1 \%$ pectinase, $0.05 \%$ macerozyme, and $0.4 \mathrm{M}$ mannitol. Nuclei were isolated using $0.5 \mathrm{ml}$ Galbraith buffer (Galbraith et al., 1983). The isolated nuclei solution was filtered through $70-\mu \mathrm{m}$ and $30-\mu \mathrm{m}$ nylon mesh, and at least $1.5 \mathrm{ml}$ of a staining solution, composed of $10 \mathrm{mM}$ Tris, $50 \mathrm{mM}$ sodium citrate, $2 \mathrm{mM} \mathrm{MgCl}_{2}$, $1 \%$ (w:v) PVP, $0.1 \%$ (v:v) Triton $\mathrm{X}-100$, and $2.5 \mathrm{mg} \mathrm{I}^{-1} 4^{\prime}, 6$-diamidino
2- phenylindole (DAPI), pH 7.5, was added to the filtered nuclei solution. After 5-10 min of staining, the stained nuclei were subjected to FCM analysis for determination of the relative nuclear DNA content on a $\log$ or linear scale histogram. At least 7,000 nuclei were counted for each sample. Results were analyzed using FlowJo software (Tree Star, Inc.). All experiments were performed in duplicate.

\section{Mitogenic activity}

Non-embryogenic cells were prepared as described above for the propyzamide block-release experiment. The initial cell density was adjusted to $0.2 \mathrm{ml} \mathrm{PCV} / 1$, with $(\mathrm{ml} \mathrm{PCV} / 1)$ defined as the packed cell volume (in $\mathrm{ml}$ ) after centrifugation at $100 \mathrm{~g}$. The cultured cells were collected on alternate days for four days and treated with an excess of a maceration solution, consisting of $10 \% \mathrm{HNO}_{3}$ and $10 \% \mathrm{CrO}_{3}$, for two days. The mixtures were then centrifuged at $100 \mathrm{~g}$ and the pellets were washed once with distilled water. Following centrifugation at $100 \mathrm{~g}$, each pellet of cells was suspended in distilled water at an appropriate cell density. Finally, the cells were counted in a hemocytometer (Thoma; Erma, Tokyo).

In all experiments, non-embryogenic cells were cultured in $50-\mathrm{ml}$ flasks containing $15 \mathrm{ml}$ medium. Each experiment was performed in duplicate and averages of results are shown along with their standard deviations.

\section{Isolation of carrot cyclin D gene}

A cDNA library was constructed from RNA of carrot non-embryogenic cells using an RT-PCR High kit (TOYOBO). A degenerate oligonucleotide primer, CD1, designed based on a highly conserved region of plant $\mathrm{D}$-type cyclins, and the oligo $(\mathrm{dT})_{20^{-}}$ P7 primer included in the RT-PCR kit were used to amplify carrot $\mathrm{D}$-type cyclin transcripts from reverse-transcribed carrot non-embryogenic cell RNA. The CD1 degenerate primer, used for 3'RACE, was as follows: 5'-AARTTYGTITTYGARGCIAARACIA-3'. Amplified PCR fragments were subcloned into pGEM-T vectors (Promega) and subsequently transformed into DH5 $\alpha$ using the freeze/thaw method. A fragment that contained a partial carrot cyclin D sequence, containing the $\mathrm{C}$ terminal end of the protein ending with a stop codon, was amplified. This information was used to design gene-specific primers to amplify the rest of the carrot cyclin D sequence from an adaptor-ligated cDNA library constructed from carrot nonembryogenic cell RNA using a Marathon(tm) cDNA kit (CLONTECH). The gene-specific primer CDC1 $\left(5^{\circ}-\right.$ CTCTTGTTACACAAATTGCCACA- 
GC-3') and the AP1 primer (CLONTECH) were used to amplify the 5' end of the carrot cyclin D transcript. Amplified PCR fragments were subcloned into pGEM-T vectors (Promega) and subsequently transformed as described above. Analysis of the nucleotide sequence showed that the fragment contained the initiation codon for the carrot cyclin D protein. The primers CDC5 (5'- CCGGGCAGGTGGAGACACATATAA - 3') and CDC3 (5'TGCTCAAGGCACAAGATTCTCTCTC-3') were used to amplify a full-length carrot cyclin D fragment.

\section{DNA sequencing}

All pGEM vectors containing the CDNA inserts of interest were purified using the QIAGEN Plasmid Purification kit according to the manufacturer's protocol. Sequencing was conducted using the Dye Terminator Primer Sequencing kit (Applied Biosystems) on an ABI 373A DNA sequencer (Applied Biosystems). Homology searches were conducted using the non - redundant combined databases of the National Center of Biotechnology Information (NCBI) using the BLAST network search. DNA and protein alignments were performed using Genetyx software.

\section{$R N A$ extraction and $R T-P C R$}

Carrot non-embryogenic cells were synchronized at the $\mathrm{M}$ phase using propyzamide. After release from propyzamide treatment, cells were collected at different time points $(0-60 \mathrm{~h})$ in medium with a low $2,4-\mathrm{D}$ concentration $\left(4.5 \times 10^{-7} \mathrm{M}\right)$ with or without PSK $-\alpha\left(1 \times 10^{-7} \mathrm{M}\right)$, and in medium with a high 2,4 - D concentration $\left(4.5 \times 10^{-6} \mathrm{M}\right)$ without PSK $-\alpha$. In addition, non - embryogenic cells were starved for seven days in phytohormone free MS medium. The starved cells were cultured under the conditions described above and collected at different time points $(0-48 \mathrm{~h})$.

Total RNAs were extracted from the collected cells using a phenol/SDS and $\mathrm{LiCl}$ method as described by Shirzadegan et al. (1991). To eliminate contaminating DNA, RNA samples were treated for $1 \mathrm{~h}$ at $37^{\circ} \mathrm{C}$ with RNase-free DNase (Promega) in the presence of ribonuclease inhibitor (RNasin, Promega). One $\mu \mathrm{g}$ of the total RNA was reversetranscribed using $25 \mathrm{pmol}$ oligo $(\mathrm{dT})_{20}-\mathrm{P} 7$ and MMLV reverse transcriptase (RNaseH-) (RT - PCR High Kit, TOYOBO) according to the manufacturer's protocol. PCR was carried out on a $1 / 100$ diluted sample of the RT products. PCR reaction conditions were as follows: $94^{\circ} \mathrm{C}, 9 \mathrm{~min}\left[94^{\circ} \mathrm{C}\right.$ for $30 \mathrm{~s}, 56^{\circ} \mathrm{C}$ for $30 \mathrm{~s}, 72^{\circ} \mathrm{C}$ for $\left.1 \mathrm{~min}\right] 30$ times; final extension at $72^{\circ} \mathrm{C}$ for $5 \mathrm{~min}$. The amplification was within the logarithmic range. Primers were designed from Dauca;CycD2 (here DcCycD2, DDBJ accession number AJ496740) and from other cell cyclerelated genes, such as Dauca;Cdc2 (here $D c C d c 2$, DDBJ accession number AJ505322), Dauca;CycB1;1 (here DcCycB1;1, DDBJ accession number $\mathrm{AB091346)}$, and $\mathrm{DCH}_{4}$ (DDBJ accession number AJ505019), which was previously isolated from carrot (unpublished data), as well as carrot ubiquitin as an internal standard. The sense-strand primers were DcCycD2F (5'-CCGTCCCATTACAGAGAGATGAAG - 3'), DeCdc2F (5'-GGCTACAAGTGTTGTGCATAGCG-3'), DcCycB1;1F (5' TACAAGATGTACAGAGAGATG-3'), DcH4F (5'-GCGTAGACGACATCCATAGCAGTG-3') and UbiquitinF (5'-AGAACCCTAGCCGACTACAACATCC-3'). The antisense-strand primers were DcCycD2R (5'-GCAGGCTTGGATTCTCCATTTC-3'), DcCdc2R (5'-CATCAACTGGTGTGGAGTAGTGGC-3'), DeCycB1;1R (5'-GATTCTCCAAGTAGTGGC-3'), DcH4F (5'-GGCGGTGTCAAGAGGATTTCAG-3') and UbiquitinR (5'-CACTTTGCCACTCTCATCCACCTT3'). PCR products were analyzed by Northern hybridization.

\section{Northern blot analysis}

RT-PCR products were electrophoresed on $1.5 \%$ agarose gels, blotted onto nylon filters (BIODYNE B) using standard procedures (Shirzadegan et al., 1991) and hybridized to carrot $D c C y c D 2, D c C d c 2$, $D C C y c B 1 ; 1, D c H 4$, and Ubiquitin probes. Probes were labeled using a Random Primed DNA Labeling kit and $\left[{ }^{32}-\mathrm{P}\right]$ ATP. Hybridization was performed overnight at $65^{\circ} \mathrm{C}$.

\section{Results}

PSK - a promotes progression of the cell cycle

In carrot non-embryogenic cell cultures, maximum cell proliferation occurred in high $2,4-\mathrm{D}$ medium without PSK - $\alpha$. PSK - $\alpha\left(1 \times 10^{-7} \mathrm{M}\right)$ did not show any additional stimulatory effect under these conditions, but did stimulate the cell proliferation in low 2,4-D medium condition (Eun et al., submitting). Therefore, the effect of PSK- $\alpha$ on the cell cycle of cells growing in low 2,4-D medium was examined using ploidy analysis of the nuclear content by means of flow cytometry. In order to determine whether PSK - $\alpha$ promotes progression of the G1 phase, non-embryogenic cells were synchronized at the $\mathrm{M}$ phase using propyzamide treatment. After release from propyzamide blocking, the ploidy distribution of cells in low 2,4-D medium with or without PSK - $\alpha$ (Fig. 1A, B) was inves- 
tigated. In low 2,4-D medium without PSK- $\alpha$, the number of $\mathrm{G} 1$ cells at $60 \mathrm{~h}$ after release from $\mathrm{M}$ phase arrest was decreased, and simultaneously the number of G2/M cells was increased (arrows in Fig. 1A, D). However, when PSK - $\alpha$ was added to low 2,4-D medium, the decrease in G1 cells and the increase in $\mathrm{G} 2 / \mathrm{M}$ cells was first observed $36 \mathrm{~h}$ after the release from propyzamide blocking (arrows in Fig. 1B, E). As a positive control, we also examined nuclei from cells grown in high 2,4-D medium without PSK- $\alpha$ (Fig. 1C, F). The results were consistent with those seen in cells from low 2,4-D medium with PSK $-\alpha$. This indicates that the length of the G1 cell cycle of some non- embryogenic cells is shortened by about $24 \mathrm{~h}$ by the addition of PSK$\alpha$ to cells in low 2,4-D medium, as compared to cells in medium without PSK $-\alpha$.

We also investigated the effect of PSK - $\alpha$ on the cell cycle outside the G1 phase. Initially, nonembryogenic cells were blocked at the $S$ phase with the addition of aphidicolin. Simultaneously with the release from aphidicolin, propyzamide was added to the synchronized cells to block them at the $M$ phase. Fig. 2 represents the time course of the percentage of the cells accumulated in the G2/M phase(s) after addition of propyzamide. In low 2,4-D medium with PSK $-\alpha$, the percentage of cells blocked in the G2/M phase(s) eight hours after propyzamide addition was higher than in cells growing in low 2,4-D medium without PSK $\alpha$. In high 2,4 D medium without PSK $-\alpha$, the percentage was identical to that in low 2,4-D medium with PSK - $\alpha$. This result shows that PSK $-\alpha$ is involved in cell cycle progression at phases other than the G1 phase.

\section{Effects of PSK - $\alpha$ on mitogenic activity}

To verify that PSK - $\alpha$ stimulates cell proliferation by promotion of cell cycle progression, we examined the mitogenic activity of PSK $-\alpha$. After non-embryogenic cells were released from propyzamide blocking at the $M$ phase, cells were counted using a hemocytometer (Fig. 3). In low 2,4-D medium, cell numbers were higher at two days after propyzamide release in the presence of PSK $-\alpha$, as compared to those grown in medium lacking PSK$\alpha$. In high 2,4-D medium without PSK - $\alpha$, mitogenic activity was identical to that in low 2,4-D medium with PSK $-\alpha$. These results indicate that PSK - $\alpha$ stimulates mitogenic activity in low 2,4-D medium.

Expression changes in cell cycle-related genes by PSK - a treatment

The above ploidy analysis indicated that progression of the cell cycle in non-embryogenic cells is

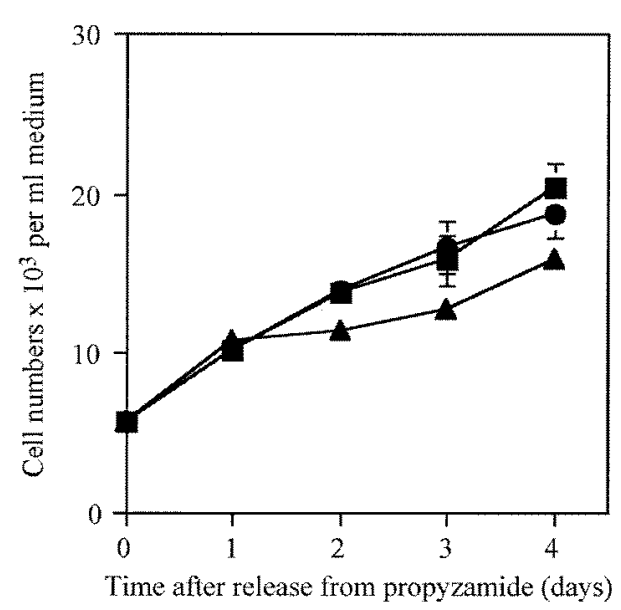

Fig. 3 Effects of PSK $-\alpha$ on cell division in nonembryogenic cells after release of propyzamide blocking. Cell numbers were counted each day for four days. The initial cell density was adjusted to $0.2 \mathrm{ml} \mathrm{PCV} /$. Each experiment includes three replicates, and all experiments were performed in duplicate. Data are the means with standard deviation (where the bar is not shown, it was too small to be displayed). $\boldsymbol{\Lambda}$, low - concentration $\left(4.5 \times 10^{-7} \mathrm{M}\right)$ of $2,4-\mathrm{D}$ without PSK - $\alpha$; low concentration $\left(4.5 \times 10^{-7} \mathrm{M}\right)$ of 2,4-D with PSK- $\alpha\left(1 \times 10^{-7} \mathrm{M}\right) ; \mathbf{a}$, high concentration $\left(4.5 \times 10^{-6} \mathrm{M}\right)$ of $2,4-\mathrm{D}$ without PSK $-\alpha$.

promoted by PSK $-\alpha$. To verify these results, we performed RT - PCR analysis using carrot cell cycle - related genes as marker genes.

First, we isolated a full-length carrot cyclin D cDNA clone, designating it Dauca;CycD2 (involves in later G1 phase, here $D c C y c D 2$ ) (Fig. 4). The nucleotide sequence and deduced amino acid sequence of carrot $D c C y c D 2$ are shown in Fig. 4. This gene contains an open reading frame of $1146 \mathrm{bp}$ encoding a protein of 382 amino acids, with a conserved region of approximately 100 amino acid residues known as the cyclin box, which is involved in cdk binding (Lee and Harlow, 1993; Jeffrey et al., 1995; Renaudin et al., 1998). An Rb interaction LxCxE motif, previously observed in the cycD cyclins, is present near the $\mathrm{N}$-terminus.

Two other carrot cell cycle--related genes, $\mathrm{DCH} 4$ (involves in $\mathrm{S}$ phase) and $D C C y C B 1 ; 1$ (involves in G2/M phase), were used along with $D c C y c D 2$ for RT-PCR. Transcript levels were investigated at various time points after releasing the cells from propyzamide blocking (Fig. 5). In low 2,4-D medium, the increase of the transcript level of $D c C y c D 2$ was observed at $30 \mathrm{~h}$ after propyzamide 
release. However, in low 2,4-D medium with addition of PSK $-\alpha$ or in high 2,4-D medium without PSK - $\alpha$ as positive control was observed at $18 \mathrm{~h}$ after propyzamide release. These increased time roughly corresponded to the later G1 phase when compared to the cell cycle expected from FCM analysis of Fig. 1. Also, in low 2,4-D medium, the increase of the transcript level of $D_{c} H 4$ and $D C C y c B 1 ; 1$ was higher with addition of PSK $\alpha$ as compared to samples from medium without PSK $-\alpha$. In the positive control culture of cells in high 2,4 - D medium without PSK- $\alpha$, the level of $D C H 4$ and $D C C y c B 1 ; 1$ transcripts increased to the same extent as in low 2,4-D medium with PSK $-\alpha$. These increased time also roughly corresponded to the $\mathrm{S}$ or $\mathrm{G} 2 / \mathrm{M}$ phase when compared to the cell cycle expected from FCM analysis of Fig. 1 .

Effect of PSK- $\alpha$ on re-entry into the cell cycle from the quiescent state

When non-embryogenic cells were cultured in phytohormone-free MS medium, they did not divide. These arrested cells can then be triggered to divide with supplementation of auxin. Nuclear DNA contents were determined for carrot non-embryogenic cells starved of phytohormones in MS medium for seven days, using flow cytometry (Fig. 6). Populations of $2 \mathrm{C}$ and $4 \mathrm{C}$ cells were observed in the arrested cells, suggesting that in non-embryogenic cells the arrest phase of the cell cycle is the G1 and G2 phases (called the G0 and G2q phases). To confirm whether PSK - $\alpha$ influences cells to re-

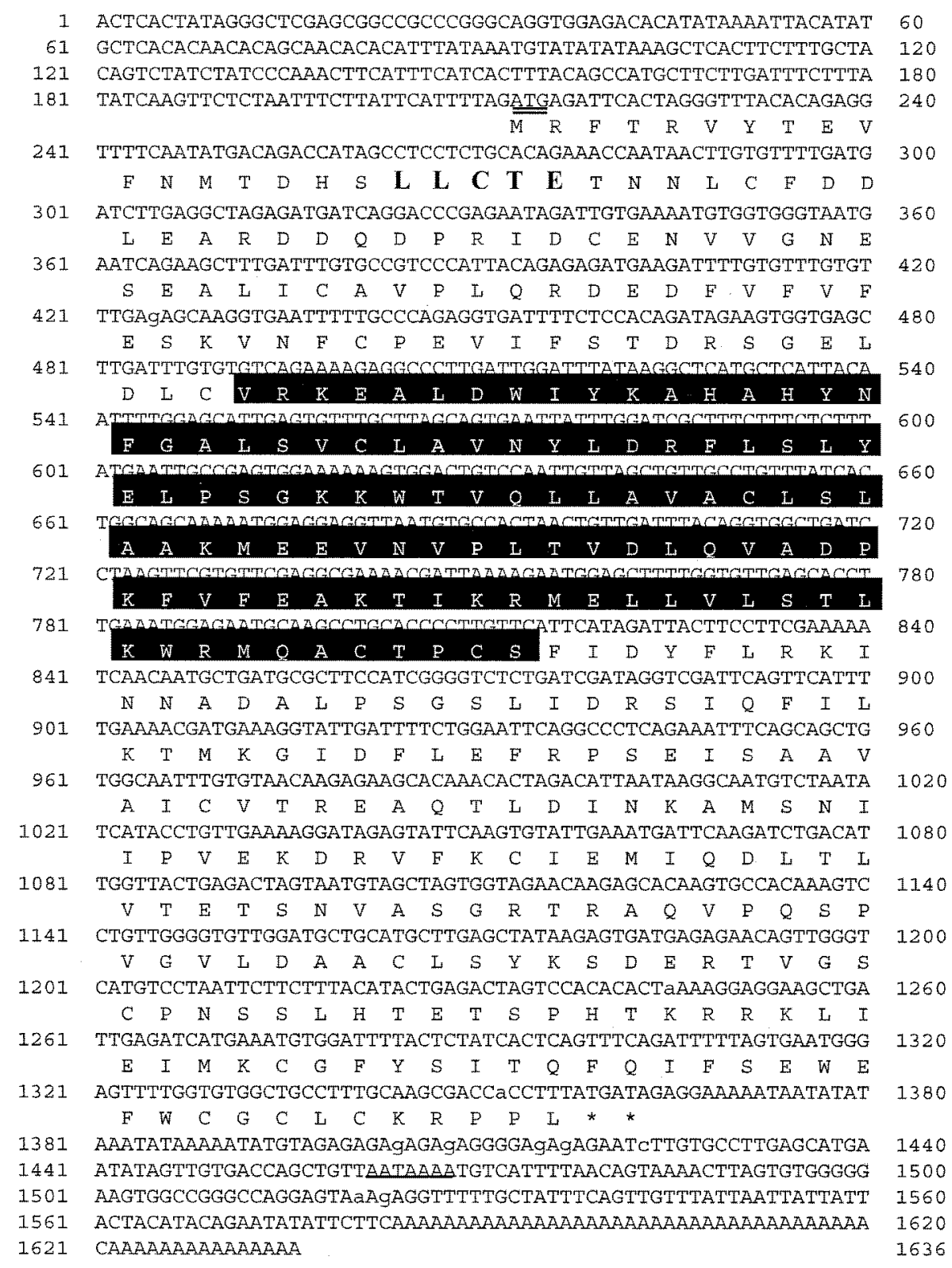

Fig. 4 Nucleotide sequence of the carrot $C y C D 2$ cDNA and deduced amino acid sequence. The initiation codon of the open reading frame is indicated by a double underline, and the LxCxE motif is shown in boldface letters. The cyclin box is shown in black, and a putative poly A signal sequence is underlined. 


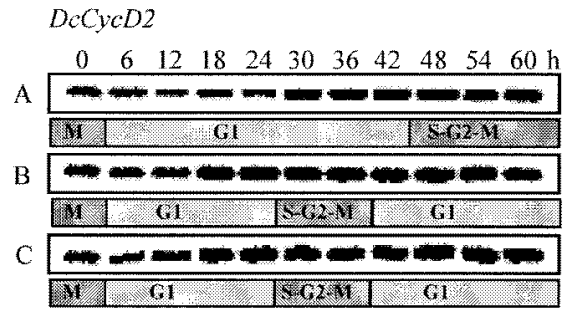

DcH4

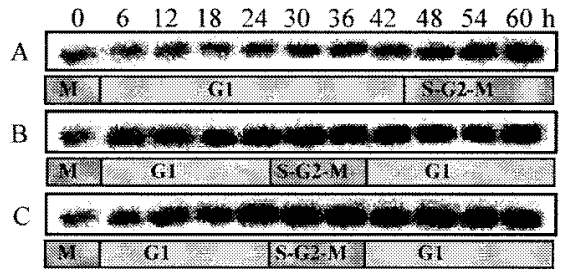

$D c C y c B 1 ; 1$

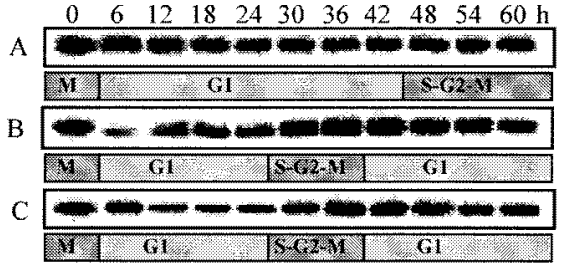

Ubiquitin
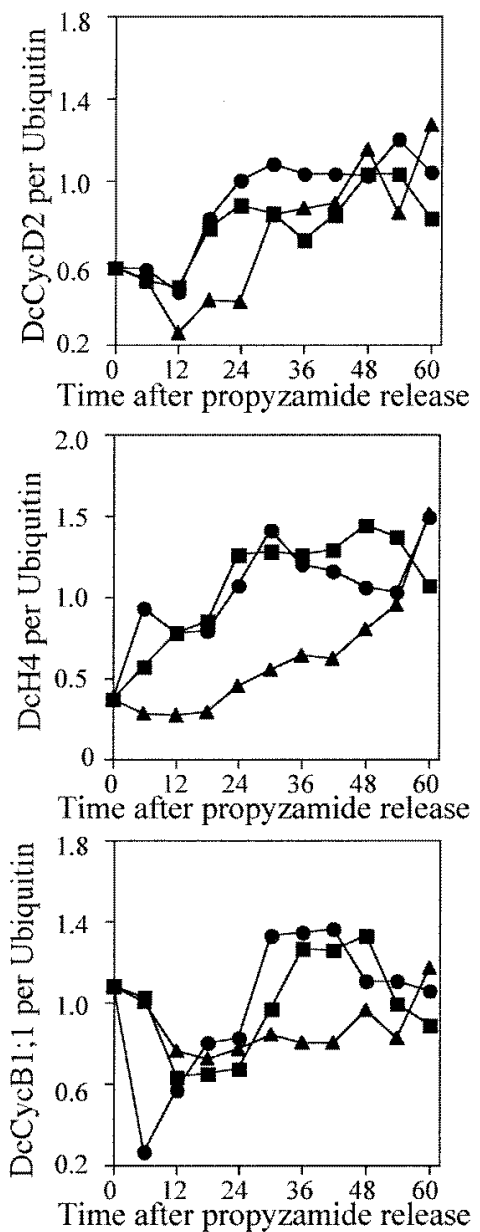

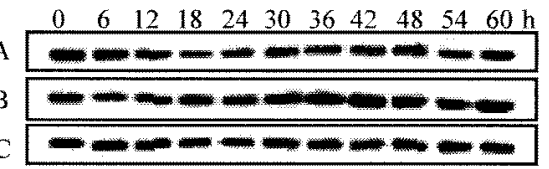

Fig. 5 RT - PCR for cell cycle-related genes and ubiquitin mRNA in non-embryogenic cells after release from propyzamide blocking. Culture conditions after propyzamide release were as follows: (A, $\mathbf{\Delta})$, low concentration $\left(4.5 \times 10^{-7} \mathrm{M}\right)$ of $2,4-\mathrm{D}$ without PSK- $\alpha$; (B, - ), low concentration $\left(4.5 \times 10^{-7} \mathrm{M}\right)$ of $2,4-\mathrm{D}$ with PSK $-\alpha\left(1 \times 10^{-7} \mathrm{M}\right)$; (C, $\left.\mathbf{\square}\right)$, high concentration $\left(4.5 \times 10^{-6} \mathrm{M}\right)$ of $2,4-\mathrm{D}$ without PSK $-\alpha$. Hybridization signals were quantified using a Fuji BAS5000 Imaging Analyzer. Quantified data were equalized by normalizing to the amount of ubiquitin signal. Rectangular bars below each expression data show the cell cycle expected from FCM analysis of Fig. 1.

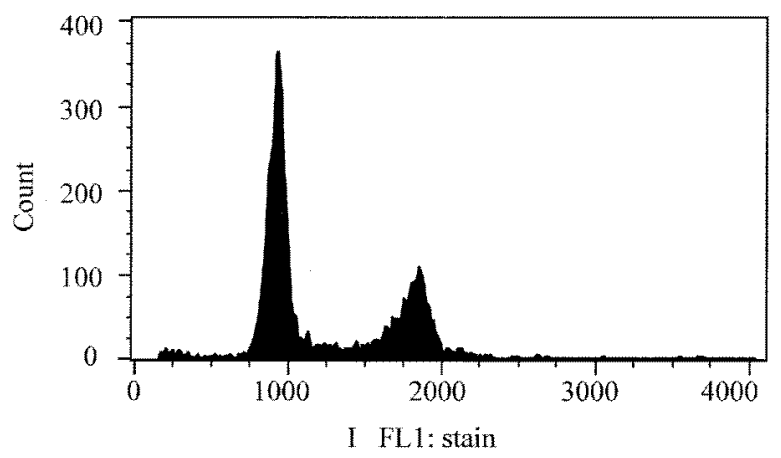

Fig. 6 The nuclear DNA C-value of quiescent nonembryogenic cells. Non--embryogenic cells cultured in phytohormone-free MS medium for seven days were used in FCM analysis. enter the cell cycle from the quiescent state, we carried out RT-PCR analysis of $D c C d c 2$ gene (express at any phase of the cell cycle) using quiescent non-embryogenic cells (Fig. 7). When the quiescent cells were cultured in low 2,4-D medium with or without PSK - $\alpha$ or in high 2,4-D medium, transcripts of $D c C d c 2$ accumulated earlier and more strongly with addition of PSK $-\alpha$ than in low 2,4-D medium lacking PSK - $\alpha$. The expression in high 2,4-D medium without PSK - $\alpha$ was earlier than that in low 2,4-D medium lacking PSK - $\alpha$, but the expression level was low than that in low $2,4-\mathrm{D}$ medium with PSK $-\alpha$. 


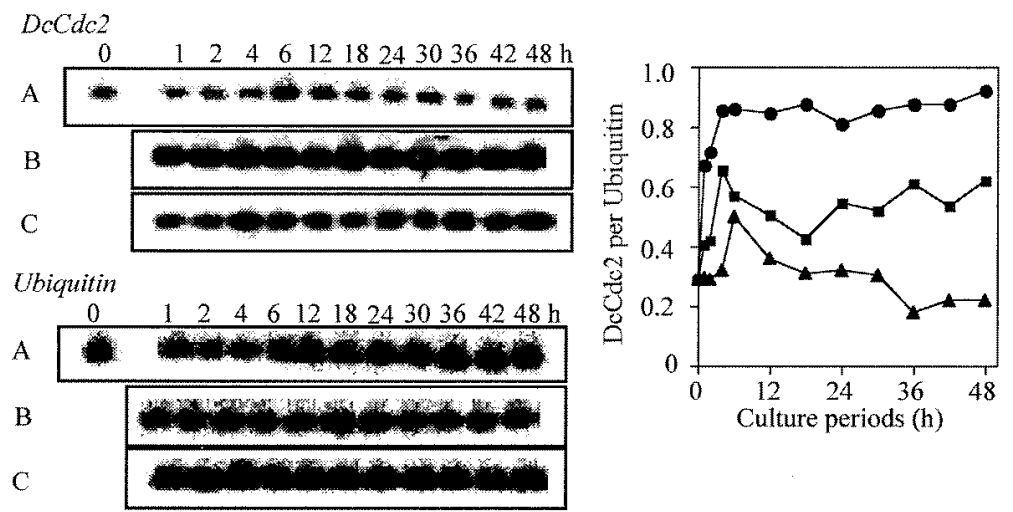

Fig. 7 RT-PCR for the $D c C d c 2$ gene in cells after re-entry into the cell cycle from the quiescent state. Quiescent non-embryogenic cells shown in Fig. 6 were cultured under the following conditions: (A, $\boldsymbol{A})$, low concentration $\left(4.5 \times 10^{-7} \mathrm{M}\right)$ of $2,4-\mathrm{D}$ without PSK $-\alpha$ ; $(\mathrm{B}, \mathbf{O})$, low concentration $\left(4.5 \times 10^{-7} \mathrm{M}\right)$ of $2,4-\mathrm{D}$ with PSK $-\alpha\left(1 \times 10^{-7} \mathrm{M}\right) ;(\mathrm{C}, \boldsymbol{\square})$, high concentration $\left(4.5 \times 10^{-6} \mathrm{M}\right)$ of $2,4-\mathrm{D}$ without PSK $-\alpha$. Hybridization signals were quantified using a Fuji BAS5000 Imaging Analyzer. The quantified data were equalized by normalizing to the amount of ubiquitin signal.

\section{Discussion}

PSK - $\alpha$ promotes progression of the G1 cell cycle

The results in this study suggest that the peptidyl plant growth factor PSK - $\alpha$ is involved in control of the cell cycle, promoting cell cycle progression in partially synchronized carrot cells. From the propyzamide block-release experiments, the G1 cell cycle that progresses slowly in low auxin conditions was stimulated by treatment with PSK - $\alpha$ to the levels seen in rapidly cycling cells growing in the presence of high concentrations of auxin (Fig. 1), suggesting that PSK $-\alpha$ is a signal involved in G1 cell cycle progression. However, cell cycle progression of only a portion of the cells was stimulated by PSK $-\alpha$. Carrot non-embryogenic cells are difficult to synchronize to the high degree achieved in tobacco BY -2 cell line that is widely used in cell cycle studies (Nagata et al, 1992; Samuels et al., 1998). However, the proliferation of tobacco BY-2 cells was not affected by PSK $-\alpha$ in any conditions examined (data not shown). Thus, we tried to make a condition for partial synchronization of cell cycle in carrot non-embryogenic-cells using cell cycle arresting reagents. Under the condition we analyzed the cell cycle progression. This is thought to be the best way at present.

The flow cytometry results were supported by RT PCR analysis of the cell cycle-related genes $D c C y c D 2, D c H 4$ and $D c C y c B 1 ; 1$ (Fig. 5). These genes were more quickly activated in the presence of PSK - $\alpha$ than in medium lacking PSK $-\alpha$. However, it is unknown why the expression of DCCyCB 1;1 rapidly decreased at $6 \mathrm{~h}$ in low 2,4-D medium with PSK $-\alpha$. In plants, both shoot and root apical meristems are mosaics of quickly and slowly cycling cells. The main difference between these two populations is the length of G1 phase (Lyndon, 1973), suggesting that this phase is the most responsive to signals that change cell-cycle length. The significance of G1 controls in commitment to the cell cycle has been shown in yeast, flies and mammals (Neufeld and Edgar 1998). In human cells, D-type cyclins act as growth factor sensors, with their expression depending more on extracellular stimuli than on the position of the cell cycle (Sherr, 1993, 1996). In transgenic tobacco plants, overexpression of $C y C D 2$ produced a reduction in the length of the cell cycle G1 phase and quicker cell cycling (Cockcroft et al, 2000). It is conceivable that D-type cyclins act as sensors for PSK - $\alpha$ in plants.

PSK- $\alpha$ promotes progression of the cell cycle outside the G1 phase

We have shown that PSK $-\alpha$ is also involved in the cell cycle outside the G1 phase. Ploidy analysis showed that the percentage of cells accumulating at the G2/M phase(s) was higher in the presence of PSK $-\alpha$ than in cultures without PSK - $\alpha$ (Fig. 2). In the plant cell cycle, both the G2 and G1 phases respond to extracellular signals such as plant growth regulators (PGRs). As mitotic activators, auxin, cytokinin and GA regulate the $\mathrm{G} 2-\mathrm{M}$ transition by activating the production of CDKs and $\mathrm{A}-$ and $\mathrm{B}-$ type cyclins (Hilde and Dirk, 2001). Auxin increases both $C D K A: 1$ and mitotic cyclin mRNA levels in roots in conjunction with the induction of cell division (Hemerly et al., 1993; Doemer et al., 1996). It has also been reported that auxin analogues influence a restriction point in the $\mathrm{G} 2$ phase of 
cell cycles in tobacco LT cells (Koens et al., 1995). PSK - $\alpha$ may regulate the $S-G 2-M$ transition of the cell cycle through a signal transduction pathway, just as the known PGRs do. However, it seems to be the activation of G1 cell cycle progression by PSK$\alpha$, rather than other cell cycle phases, that is the main influence on the stimulation of cell proliferation. The importance of the G1 phase is not necessarily due to its absolute duration, but rather to the fact that it is a period when there is considerable variation between populations of cells multiplying at different rates (Heath, 1993).

PSK - $\alpha$ enhances re-entry into the cell cycle from the quiescent state

When non-embryogenic cells were cultured in phytohormone-free medium, the cells were arrested mainly in the $\mathrm{G} 1$ phase, although arrested cells in the G2 phase were also observed. To date, most data show G0 (non-cycling G1) as the resting place for the majority of non-cycling cells in both plants and animals. Our data indicate that PSK - $\alpha$ has a role in the re-entry of quiescent cells into the cell cycle. From RT-PCR analysis of cells grown in starvation conditions, $D c C d c 2$ was remarkably activated by addition of PSK - $\alpha$ as compared to cells in medium lacking PSK - $\alpha$ (Fig. 7). The stimulation activity of PSK $\cdots \alpha$ was similar to that of rapidly dividing cells in auxin-supplemented medium. Cytokinin treatment can cause cells to undergo the $\mathrm{G} 0-$ to-G1 transition (Nougarede et al, 1996). Cytokinin also increases the proportion of rapidly cycling cells in meristems by inducing G0 cells to enter the cell cycle (Gonthier et al., 1987). Nicotiana plumbaginifolia suspension-cultured cells arrested in $\mathrm{G} 2$ by cytokinin starvation exhibit high levels of inactive Cdc2 phosphorylated at Tyr15 (Zhang et al., 1996). One immediate consequence of cytokinin-induced entry into mitosis is dephosphorylation of Cdc2. As in tobacco suspension-culture cells, carrot nonembryogenic cells showed low levels of $D c C d c 2$ mRNA in media with low concentrations of auxin, but transcription of this gene conspicuously increased with supplementation of PSK- $\alpha$ or high levels of auxin (Fig. 7). It is possible that PSK- $\alpha$ and auxin may also be involved in the dephosphorylation of $D c C d c 2$ for re-entry into mitosis, although no direct evidence for this is shown in this paper.

In higher plants, two PGRs, auxin and cytokinin, have long been implicated in control of the cell cycle (Jacqmard et al., 1994; Gray and Estelle 1998). In recent years, considerable progress has been made in understanding the core cell cycle machinery. However, it remains unknown how plant growth regulators can influence this machinery. Our previous results showed that proliferation of carrot non-embryogenic cells was stimulated by treatment with PSK - $\alpha$ under low-auxin conditions but not under high-auxin conditions, because of the rapid cell division induced by high levels of auxin (Eun $e t$ al., submitting). We also found that in the presence of PSK $-\alpha$ but the absence of auxin, cell proliferation was not stimulated (Eun et al, submitting), suggesting that auxin is required for the stimulation of cell proliferation through PSK $-\alpha$. In this paper, we suggest that PSK - $\alpha$ is involved in the regulation of the plant cell cycle through a signal transduction pathway mediated by auxin. We are now investigating the relationship between PSK $-\alpha$ and cell division using carrot explants. Further research should elucidate the function of PSK- $\alpha$ in regulation of the cell cycle, and also help to elucidate the roles of plant growth regulators as control mechanisms in the cell division cycle.

\section{Acknowledgments}

We thank Dr. K. Watanabe of the University of Tsukuba for critical reading of the manuscript. This work was supported in part by a Grant-in-Aid from the "Research for the Future" program of the Japan Society for the Promotion of Science (JSPS-RFTF 00L01601); and by a Grant-in-Aid and Special Coordination Funds from the Ministry of Education, Culture, Sports, Science, and Technology, of Japan.

\section{References}

Bellincampi, D., Morpurgo, G., 1987. Conditioning factor affecting growth in plant cells in culture. Plant Sci., $\mathbf{5 1}$ $83-91$.

Bellincampi, D., Morpurgo, G., 1989. Evidence for the presence of a second conditioning factor in plant cell culture. Plant Sci., 65: 125-130.

Birnberg, P. R., Somers, D. A., Brenner, M. L., 1988. Chatacterization of conditioning factors that increase colony formation from black Mexican sweet corn protoplast. J. Plant Physiol., 132: 316 - 321 .

Chen, Y. F., Matsubayashi, Y., Sakagami, Y., 2000. Peptide growth factor phytosulfokine- $\alpha$ contributes to the pollen population effect. Planta, 211: 752-755.

Cockcroft, C. E., den Boer, B. G. W., Healy, J. M. S., Murray, J. A. H., 2000. Cyclin D control of growth rate in plants. Nature, 405: $575-579$

Doerner, P., Jorgensen, J. E., You, R., Steppuhn, J., Lamb, C., 1996. Control of root growth and development by cyclin expression. Nature, 380:520 - 523.

Eun, C. H., Ko, S. M., Matsubayashi, Y., Sakagami, Y., Kamada, H., Phytosulfokine a requires auxin to stimulate carrot non-embryogenic cell proliferation. Plant Physiol. Biochem. (in press).

Galbraith, D. W., Harkins, K. R., Maddox, J. M., Ayres, N. M., Sharma, D. P., Firoozabady, E., 1983. Rapid flow 
cytometric analysis of the cell cycle in intact plant tissues. Science, 220: 1049-1051.

Gonthier, R., Jacqmard, A., Bernier, G., 1987. Changes in cell cycle duration and growth fraction in the shoot meristems of Sinapis during floral transition. Planta, 170: $55-59$.

Gray, W. M., Estelle, M., 1998. Biochemical genetics of plant growth. Curr. Opin. Biotechnol, 9: 196-201.

Hanai, H., Matsuno, T., Yamamoto, M., Matsubayashi, Y., Kobayashi, T., Kamada, H., Sakagami, Y., 2000. A secreted peptide growth factor, phytosulfokine, acting as a stimulatory factor of carrot somatic embryo formation. Plant Cell Physiol., 41: 27- 32.

Heath, J. K., 1993. An introduction to cell proliferation. In: Rickwood, D. (Ed.): Growth Factors, pp. 3-5. Oxford University Press, New York.

Hemetly, A. S., Ferreira, P., Engler, J. A., Van Montagu, M., Engler, G., Inzé, D., 1993, cdc2a expression in Arabidopsis is linked with competence for cell division. Plant Cell, 5: $1711-1723$.

Hilde, S., Dirk, I., 2001. When plant cells decide to divide. Trends Plant Sci., 6: 350-364.

Huang, B., Bird, S., Kemble, R., Simmonds, D., Keller, W., Miki, B., 1990. Effects of culture density, conditioned medium and feeder cultures on microspore embryogenesis in Brassica napus L. cv. Topas. Plant Cell Rep., 8: $594-597$.

Jacqmard, A., Houssa, C., Bernier, O., 1994. Regulation of the cell cycle by cytokinin. In: Mok, D. W. S., Mok, M. C. (Eds.): Cytokinins, Chemistry, Activity and Function, pp. 197-215. CRC Press, Boca Raton Florida.

Jeffrey, P. D., Russo, A. A., Polyak, K., Gibbs, E., Hurwitz, J., Massague, J., Pavletich, N. P., 1995. Mechanism of CDK activation revealed by the structure of a cyclin ACDK2 complex. Nature, 376: 313-320.

Kobayashi, T., Eun, C. H., Hanai, H., Matsubayashi, Y., Sakagami, Y., Kamada, H., 1999. Phytosulfokine- $\alpha$, a peptidyl plant growth factor, stimulates somatic embryogenesis in carrot. J. Exp. Bot., 50: 1123-1128.

Koens, K. B., Nicoloso, F. T., Harteveld, M., Libbenga, K. R., Kijne, J. W., 1995. Auxin starvation results in G2arrest in suspension cultured tobacco cells. J. Plant Physiol., 147: 391 - 396.

Lee, E. M., Harlow, E., 1993. Sequences within the conserved cyclin box of human cyclin $\mathrm{A}$ are sufficient for binding to and activation of $\mathrm{CDC} 2$ kinase. Mol. Cell Biol., 13: 1194-1201.

Lyndon, R. F., 1973. The cell cycle in the shoot apex. In: Balls, M., Billett, F. S. (Eds.): The Cell Cycle in Development and Differentiation, pp. 176-183. Cambridge University Press, Cambridge.

Matsubayashi, Y., Sakagami, Y., 1996. Phytosulfokine, sulfated peptides that induce the proliferation of single mesophyll cells of Asparagus officinalis L. Proc. Nati. Acad. Sci. U. S. A., 93: 7623-7627.

Matsubayashi, Y., Takagi, L., Sakagami, Y., 1997. Phytosulfokine - $\alpha$, a sulfated pentapeptide, stimulates the proliferation of rice cells by means of specific high - and low - affinity binding sites. Proc. Natl. Acad. Sci. U. S.
A., 94: $13357-13362$.

Matsubayashi, Y., Takagi, L., Omura, N., Morita, A., Sakagami, Y., 1999. The endogenous sulfated pentapeptide phytosulfokine $\alpha$ stimulates tracheary element differentiation of isolated mesophyll cells of Zinnia. Plant Physiol., 120: 1043-1048.

Matsubayashi, Y., Sakagami, Y., 2000. 120- and 160-kDa receptors for endogenous mitogenic peptide, phytosulfokine $-\alpha$, in rice plasma membranes. J. Biol. Chem., 275: $15520-15525$.

Matsubayashi, Y., Ogawa, M., Morita, A., Sakagami, Y., 2002. An LRR receptor kinase involved in perception of a peptide plant hormone, phytosulfokine. Science, 296: $1470-1472$.

Murashige, T., Skoog, F., 1962. A revised medium for rapid growth and bioassays with tobacco tissue cultures. Physiol. Plant., 15: 473-497.

Nagata, T., Nemoto, Y., Hasezawa, S., 1992. Tobacco BY2 cell line as the "HeLa" cell in the cell biology of higher plants. Int. Rev. Cytol., 132: 1 - 30.

Neufeld, T. P., Edgar, B. A., 1998. Connections between growth and the cell cycle. Curr. Opin. Cell Biol., 10: $784-790$.

Nougarede, A., Silveira, C. E., Rondet, P., 1996. In nature dormant buds and in vitro dormant-like buds of Fraxinus excelsior L. Protoplasma, 190: 16-24.

Renaudin, J. P., Savoure, A., Philippe, H., Van Montagu, M., Inzé, D., Rouze, P., 1998. Characterization and classification of plant cyclin sequences related to $A$ - and $B$ type cyclins. In: Francis, D. et al. (Eds.): Plant Cell Division, pp. 67-98. Portland Press, London.

Samuels, A. L., Meehl, J., Lipe, M., Stachelin, L. A., 1998. Optimizing conditions for tobacco BY-2 cell cycle synchronization. Protoplasma, 202: 232-236.

Satoh, S., Kamada, H., Harada, H., Fujii, T., 1986. Auxincontrolled glycoprotein release into the medium of embryogenic carrot cells. Plant Physiol, 81: 931-933.

Schaffler, E., Koop, H. U., 1990. Single cell nurse culture of tobacco protoplasts: physiological analysis of conditioning factors. J. Plant Physiol., 137: 95-101.

Sherr, C. J., 1993. Mammalian G1 cyclins. Cell, 73: 1059 1065.

Sherr, C. J., 1996. Cancer cell cycles. Science, 274: 16721677.

Shirzadegan, M., Christie, P., Seemann, J. R., 1991, An efficient method for isolation of RNA from tissue cultured plant cells. Nucleic Acids Res., 19: 6055.

Somers, D. A., Birnberg, P. R., Petersen, W. L., Brenner, M. L., 1987. The effect of conditioned medium on colony formation from black Mexican sweet corn protoplast. Plant Sci, 53: 249-256.

Stuart, R., Street, H. E., 1969. Studies on the growth in culture of plant cells. IV. The initiation of division in suspensions of stationary phase cells of Acer pseudoplatanus L. J. Exp. Bot., 20: 556-571.

Yamakawa, S., Sakuta, C., Matsubayashi, Y., Sakagami, Y., Kamada, H., Satoh, S., 1998a. The promotive effects of a peptidyl growth factor, phytosulfokine $-\alpha$, on the formation of adventitious roots and expression of a gene 
for a root- specific cystatin in cucumber hypocotyls. J. Plant Res., 111: 453-458.

Yamakawa, S., Matsubayashi, Y., Sakagami, Y., Kamada, H., Satoh, S., 1998b. Promotion by a peptidyl growth factor, phytosulfokine- $\alpha$, of chlorophyll formation in etiolated cotyledon of cucumber. Biosci. Biotechnol. Biochem., 62: 2441-2443.

Yamakawa, S., Matsubayashi, Y., Sakagami, Y., Kamada, H., Satoh, S., 1999. Promotive effects of the peptidyl plant growth factor, phytosulfokine- $\alpha$, on the growth and chlorophyll content of Arabidopsis seedlings under high night-temperature conditions. Biosci. Biotechnol. Biochem., 63: 2240-2243.

Yang, G., Shen, S., Kobayashi, T., Matsubayashi, Y., Sakagami, Y., Kamada, H., 1999. Stimulatory effects of a novel peptidyl plant growth factor, phytosulfokine- $\alpha$, on the adventitious bud formation from callus of Antirrhinum majus. Plant Biotechnol., 16: 231-234.

Yang, H., Matsubayashi, Y., Hanai, H., Nakamura, K., Sakagami, Y., 2000. Molecular cloning and characterization of OsPSK, a gene encoding a precursor for phytosulfokine $-\alpha$, required for rice cell proliferation. Plant Mol. Biol., 635: 635-647.

Yang, H., Matsubayashi, Y., Nakamura, K., Sakagami, Y., 2001. Diversity of Arabidopsis genes encoding precursors for phytosulfokine, a peptide growth factor. Plant Physiol, 127: 842-851.

Zhang, K., Letham, D. S., John, P. C. L., 1996. Cytokinin controls the cell cycle at mitosis by stimulating the tyrosine dephosphorylation and activation of p34 $4^{\mathrm{ddc} 2}$.. like H1 histone kinase. Planta, 200: 2- 12. 